\title{
With Swinish Phrase Soiling Their Addition: \\ Epistemic Injustice, Academic Freedom, and the Shakespeare Authorship Question
}

By Michael Dudley

\begin{abstract}
This chapter argues that the near-universal exclusion from the academy of the Shakespeare Authorship Question (or $S A Q$ ) represents a significant but little-understood example of an internal threat to academic freedom. Using an epistemological lens, this chapter examines and critiques the invidious and marginalizing rhetoric used to suppress such research by demonstrating the extent to which it constitutes a pattern of epistemic vice: that, by calling skeptics "conspiracy theorists" and comparing them to Holocaust deniers rather than addressing the substance of their claims, orthodox Shakespeare academics risk committing acts of epistemic vice, injustice and oppression, as well as foreclosing potentially productive lines of inquiry in their discipline. To better understand this phenomenon and its implications, the chapter subjects selected statements to external criteria in the form of the Association of College and Research Libraries' 2015 Framework for Information Literacy for Higher Education, which provides a set of robust normative dispositions and knowledge practices for understanding the nature of the scholarly enterprise. The analysis reveals that the proscription against the Shakespeare Authorship Question constitutes an unwarranted infringement on the academic freedom not only of those targeted by this rhetoric, but - by extension - of all Shakespeare scholars as well.
\end{abstract}




\section{Introduction}

Any substantive objection [to new ideas] is permissible and encouraged; the only exception being that ad hominem attacks on the personality or motives of the author are excluded. It does not matter what reason the proponent has for advancing his ideas or what prompts his opponents to criticize them: all that matters is whether the ideas are right or wrong, promising, or retrogressive.

\section{- Carl Sagan ${ }^{1}$}

The June 2019 issue of The Atlantic featured an essay by Elizabeth Winkler, "Was Shakespeare a Woman?" which, following a summary of the evidentiary weakness of the traditional attribution of the plays and poems of Shakespeare to the gentleman actor from Stratford-Upon-Avon, outlined the proposition that the poet Emilia Bassano might be a potential alternative candidate for their authorship (Winkler, 2019a). Anticipating controversy, the editors of The Atlantic let other Shakespeare experts weigh in on her claims, including Columbia University’s James Shapiro, who decried Winkler's piece as “fiction” emerging from “an alternate universe, inhabited by conspiracy theorists...recycl[ing] stale and feeble arguments all too familiar to anyone who has dealt with this fringe movement" (Shapiro, 2019a, para. 2). Renowned Shakespearean actor Sir Mark Rylance, on the other hand, commended Winkler for her article and called out her critics for their vitriolic attacks, arguing that maintaining an open mind on the authorship of these works enriches our understanding of them (Rylance, 2019).

\footnotetext{
${ }^{1}$ Sagan 1979, 82-83.
} 
Much of the media response to Winkler's piece was negative. For example, Dominic Green, writing in The Spectator, reiterated Shapiro's accusation of "conspiracy theory" while offering a particularly distasteful analogy:

The 'case' for anyone but Shakespeare is always a fantasy in pursuit of facts. Winkler's article, like every case for Shakespeare not having been Shakespeare, repeatedly commits the elementary error of historical writing. Absence of evidence does not mean evidence of absence. It is strange that Shakespeare doesn't refer to books in his will. But it doesn't mean that he didn't read. Hitler, after all, did not attend the Wannsee Conference. But that doesn't mean he didn't order the Holocaust (Green, 2019, para 6).

By maligning such scholarship as "conspiracy theories" as well as levelling ad hominem attacks on those skeptical of the traditional Shakespeare biography, orthodox scholars and pundits such as Shapiro and Green are, in essence, levelling against them a charge of epistemic vice, or accusing them of illegitimate "practices and concepts relating to knowledge, understanding, certainty, belief [and] doubt" (Kidd, 2016, p. 181). As will be argued below, however, these charges are frequently imbued with highly prejudicial and stigmatizing rhetoric rather than substantive counterargument, amounting to acts of epistemic vice in their own right.

In this chapter, we shall be examining this pattern of marginalization to demonstrate a key example of an infringement on academic freedom from within the academy, of attempts to silence legitimate discourse and prejudicially foreclose potentially fruitful avenues of scholarship. It will examine this case according to several relevant theoretical contexts concerning epistemic virtue before analyzing the rhetoric employed against Shakespeare skeptics according to an external criterion of scholarly soundness. The chapter concludes with the pedagogical reasons for welcoming the debate in the contemporary academy in the spirit of scholarly humility. 
We must first establish essential terminology. The terms Stratfordian or orthodox refer to the traditional attribution of the plays and poems to William Shakspere of Stratford-Upon-Avon and believers in it, while criticism of the traditional attribution will be referred to as postStratfordian, which would include the broad category anti-Stratfordian (agnostic skeptics) as well as advocates of particular candidates (e.g., Edward de Vere, 17 $7^{\text {th }}$ earl of Oxford, Francis Bacon, etc.). Furthermore, references to Shakespeare indicate the Author (whomever he was) while Shakspere denotes the gentleman from Stratford-Upon-Avon controversially assumed to be the author.

\section{Context: Internal Threats to Academic Freedom}

Debates over academic freedom in the $21^{\text {st }}$ Century have grown increasingly complex and fraught as those on the political right have sought to target progressive academics both for their left-leaning, counterhegemonic political views (Wilson, 2008), or for what they see as the corrosive effects of policing language and ideas deemed offensive or harmful in the name creating "safe spaces" on campus (Williams, 2016). At the same time, critics on the left cite the undue influence of neoliberalism and corporatization on universities, and a concomitant reliance on external, corporate funding as a threat to academic freedom (Turk 2008). In fact, there have been accusations that university administrators have attempted to suppress findings unfriendly to their donors, while individual scholars, unable to resist the allure of such funding, have allowed it to compromise the integrity of their research (Washburn 2006). When forces external to the university seek to overtly impose limits on academic freedom on ideological bases, for many in the academy there is a clear imperative to reject these efforts, and scholars and their societies have proven quick to act: For example, the American Association of University Professors condemned conservative pundit David Horowitz's attempts to legislate both federally and at state levels an 
"Academic Bill of Rights" targeting the so-called "indoctrination" of students by left-leaning professors (American Association of University Professors, 2003).

The dialogic landscape becomes less clearly defined when pressures to suppress and exclude certain forms of inquiry and course content come from within the academy, indeed, the professoriate itself. As James Turk of Canada's Centre for Free Expression points out in the introduction to his book Academic Freedom in Conflict (2014), an important implied limitation on academic freedom is that faculty may not infringe upon the academic freedom of their colleagues. The fact remains, however, that such intramural policing does occur. Referring to such practices as "forum control," Sullivan (2000) warns that denying unorthodox scholars access to a given discipline's major publications and subjecting them to ridicule risks "cutting off lines of possible research and, perhaps, blinding itself to avenues of understanding" (p. 142).

It is true that in some cases (as in, for example, experimentation on children or subjecting unknowing participants to potentially traumatizing experiences) such proscriptions are generally understood as perfectly justifiable on ethical, legal or moral grounds. There is a defensible consensus that some questions best remain unanswered: "forbidden knowledge" that may not be reasonably pursued without gravely compromising the legitimacy of the field in question - to say nothing of the humanity of the researchers themselves (Kempner, Merz \& Bosk, 2011). On the other hand, taboos can also persist for purely ideological or paradigmatic reasons, and as a result of closed, circular systems of inquiry the margins of certain disciplines may become demarcated by significant "unknown knowns" reinforced by its members to maintain the status quo (Jackson, 2012). Such, it shall be argued below, is the case with the question regarding the authorship of the works of Shakespeare. 


\section{Background: The Shakespeare Authorship Question.}

"There is a mystery about the identity of William Shakespeare. The mystery is this: why should anyone doubt that he was William Shakespeare, the actor from Stratford-upon-Avon?" So asks Jonathan Bate in his book The Genius of Shakespeare (1998, p. 65). Unfortunately for Bate, a few Stratfordians are willing to admit the reasons for doubt. David Ellis, in his The Truth About William Shakespeare: Fact, Fiction and Modern Biographies (2012), criticizes the Bard's wouldbe biographers for making up "facts" about their subject because so little is actually known about the Stratford gentleman. While convinced that Shakspere of Stratford was the author, he concludes that the Shakespearean biographical enterprise is a hopeless one. More damning still are the conclusions of Bruce Danner (2011) who writes that,

[Shakespeare scholars] have failed to establish a clear and convincing portrait of Shakespeare, not merely to the popular audience, but to ourselves. Until we do, or can provide clear explanations for why we cannot, authorship conspiracy theories will persist, continuing to cast the "dark shadow[s]" that haunt our claims to knowledge (pp. 156-157).

Despite the enduring public fascination with the debate regarding the authorship of the works of Shakespeare, investigation into it remains almost exclusively the domain of independent researchers, or academics associated with departments other than English literature. To doubt the attribution of the plays and poems to the apparently uneducated but miraculously gifted malt merchant of Stratford-Upon-Avon, or to pursue the question as an aspiring doctoral student or untenured faculty is to court career-ending disapprobation. Post-Stratfordian scholars and researchers are routinely subjected to rhetoric so extreme that the late Richmond Crinkley, director of programs at the Folger Shakespeare Library between 1969 and 1973, likened it to “some bizarre mutant racism" (Crinkley, 1985, p. 518). Post-Stratfordians are routinely dismissed 
as "conspiracy theorists," compared with "flat-Earthers," creationists and even Holocaust deniers. This latter calumny is particularly egregious, and indeed dangerous. As Bryan Wildenthal (2016) explains,

Does it not occur to these tenured "experts" just how reckless and harmful such comparisons are? ...Leading academics do set a tone. Does it not occur to them how much it disrespects the victims of the worst (and best-documented) atrocity in human history? That such comparisons give aid and comfort to those who actually do deny...the reality of the Holocaust, by linking them to people with incomparably more reasonable and wellfounded doubts relating to the [Shakespeare Authorship Question], including many distinguished judges, scholars, and professionals in various fields? (p. 8)

Mainstream orthodox Shakespeare scholars (and the pundits who regularly call upon them for comment in the media) routinely deal with the Authorship Question not by addressing the substance of post-Stratfordian criticisms but by questioning the sanity and motives of the doubters themselves. Samuel Schoenbaum's remarks in his book Shakespeare's Lives (1970) typify these attacks. He sees in doubters "a pattern of psychopathology ... paranoid structures of thought ... hallucinatory phenomena" and "descent, in a few cases, into actual madness" or at the very least the "manifestations of the uneasy psyche" (p. 608).

This pattern of argumentation is known as the Bulverist fallacy - assuming a speaker to be wrong, and then ascribing their supposed error to psychological motivations, rather than addressing their claims (Lewis, 1970). ${ }^{2}$ As a rhetorical strategy it has proven quite effective over the years in marginalizing post-Stratfordian scholarship, excluding it from mainstream Shakespeare journals and relegating most of it to smaller, independent publishers or online

\footnotetext{
${ }^{2}$ In his chapter "Bulverism" in God in the Dock (1970), Lewis makes up an imaginary figure, Ezekiel Bulver, whom he credits with inventing this rhetorical strategy.
} 
venues. ${ }^{3}$ To create a legitimate dialogic space for such investigations in the academy, it is therefore essential that these strategies themselves be identified and delegitimized.

\section{Theory and Methods}

In this chapter, the attacks against proponents of the Shakespeare Authorship Question (SAQ) shall be framed theoretically as forms of epistemic injustice and oppression (Dotson, 2014; Fricker, 2007), before subjecting selected statements by Stratfordians to external, unrelated and disinterested criteria in the form of the Association of College and Research Libraries' Framework for Information Literacy for Higher Education (ACRL Board of Directors, 2015), which provides a set of robust normative dispositions and knowledge practices for the academic researcher.

Note that the belief in the Shakespeare of tradition per se does not concern us. Such arguments for and against have been set out extensively elsewhere (Anderson, 2006; Edmondson \& Wells, 2013; Gilvary, 2018; McCrea, 2005; Ogburn, 1992; Price, 2001; Shahan \& Waugh, 2013). I am also cognizant of the possibility that the present argument will be compared to the cynical strategy employed by creationists to insinuate their agenda into the education system by "teaching the controversy" in the absence of actual scientific evidence supporting their argument. Such comparisons do not apply here: I allow the Stratfordian tradition has a valid place in the academy, but I am arguing that the exclusionary rhetoric used by some scholars to triumphantly assert the inviolability of the tradition and to denigrate dissident scholars has no place in the academy whatsoever. To better understand the nature of this rhetoric, we must first situate it in terms of theories of virtue epistemology.

\footnotetext{
${ }^{3}$ For examples, see Hampton-Reeves, 2013 and Shapiro, 2010.
} 


\section{Theory: Epistemic Virtues and "Conspiracy Theories"}

Virtue epistemology (VE) is a branch of philosophy that seeks to understand the generation of knowledge by viewing individuals and groups as knowing agents. Where conventional epistemologists are concerned with what constitutes the construction of true beliefs at the individual level, VE introduces the roles personal traits and group dynamics play in these processes, and in their social reproduction. In other words, VE studies assist us in understanding the creation and maintenance of epistemological systems, which include "the situatedness of knowers, (2) the interdependence of our epistemic resources and (3) the resilience of our epistemological systems" (Dotson, 2014, p. 120).

At the social level, virtue epistemologists consider the importance of luck (or one's situatedness in the environment) in the ability of individuals or groups to acquire knowledge: that, given one's fortunate circumstances it may take less effort to acquire knowledge while in other settings it is much more difficult or impossible to acquire certain forms of knowledge regardless of one's abilities (Pritchard, 2014). ${ }^{4}$ We also need to acknowledge that "our epistemic socialisation is shaped by entrenched injustices, invidious stereotypes, and disruptive biases" (Kidd 2016, p. 190) which encourage epistemic vice.

According to Kidd (2016), epistemic vices consist of poor epistemic conduct (deliberately ignoring evidence) and character (such as arrogance and dogmatism). To charge other parties of committing epistemic vice is to accuse them of possessing a blameworthy psychology such that they are closed-minded and acting in bad faith towards other knowers. However, when one's

\footnotetext{
${ }^{4}$ Without acknowledging their debt to virtue epistemologists per se, post-Stratfordians make this very argument against the Stratford mythology: that Shakspere of Stratford - regardless of any innate talent he might have possessed - was a deprived situated knower in a remote, bookless provincial town, far removed from an environment that might have equipped him to write the incredibly erudite and evidently aristocratic Shakespeare plays and poems (e.g., Ogburn 1992, chapters 1-4).
} 
charge of vice is "ill-formed, poorly-reasoned, or evidentially empty" that, in itself, is an act of epistemic vice (p. 185).

Since the most common epistemic vice charge in this case is that post-Stratfordians are promoting a "conspiracy theory" it is important that we examine this specific category from an epistemic perspective. According to Husting and Orr (2007), the labelling of any social or political critique as being "just a conspiracy theory" is a "pre-emption of the scholarly and investigation process" because it is universally accepted that conspiracies occur all the time (Watergate, Iran-Contra, Enron etc.), and each case requires that investigators carefully consider the available evidence (p. 131). The intended purpose of the charge is therefore to pejoratively call the speaker's character into question, while mischaracterizing their claims and equating them with other, totally unrelated or clearly absurd claims (Husting and Orr, 2007).

Husting and Orr (2007) further criticize political scientists and journalists for unquestioningly assuming the internal validity of the term "conspiracy theorist" and limiting their inquiries into asking why such people hold the beliefs they do, rather than addressing the substance of their claims, which are thus illegitimatized. The other rhetorical tool used against doubters is to then compare the conspiracy theory in question to a single or extreme example (e.g., Holocaust denial) to argue that all conspiracy theories may be dismissed out of hand. In this way, Husting and Orr argue, such writers "perform boundary maintenance" in a given discipline by "constructing the stigmatized other" (p. 141) such that "certain ways of knowing, thinking, and talking about power are encouraged while others are rendered abnormal" and public discourse is effectively policed (p. 144). In this view, the charge of "conspiracy theory" becomes a "mechanism of exclusion... by which critical questions and claims are symbolically delegitimized...a reframing device that neutralizes questions about power and motive while 
turning the force of challenges back onto their speakers, rendering them unfit public interlocutors" (p. 146).

When certain knowers are classified according to a prejudged category and have their knowledge and perspectives deemed to be outside the realm of acceptable discourse, they can then be said to have suffered epistemic injustice. In her 2007 book Epistemic Injustice: Power and the Ethics of Knowing, English philosopher Miranda Fricker describes how people may be "wronged specifically in [their] capacity as...knower[s]" (p. 20). Fricker describes this as testimonial injustice, in which a knower/teller is not believed by their audience owing to unwarranted prejudice against their social category. ${ }^{5}$ While she concentrates on people being dismissed and disqualified for reasons of race and gender, this form of injustice includes instances when a "new idea or hypothesis" is rejected by its intended audience owing to harmful stereotyping (p. 60). In any case, the result is that these speakers are systematically degraded as knowers and as people.

Elaborating on Fricker's work, Dotson (2014) speaks of epistemic oppression: when persistent exclusion from participating in a field of knowledge production hinders the knower's ability to contribute to it - and effect change within it. In this credibility economy, certain classes of knowers are granted privileged default credibility while others are systematically deemed to be less credible. In order for those oppressed to be heard and understood, changes to the structures of epistemic power are required, that privileged credible knowers must be willing to lower the value of their own credibility.

\footnotetext{
${ }^{5}$ Fricker's second type, hermeneutical injustice, is a result of prejudice against broad social categories of knowers (e.g., race, ethnicity, sexuality) and does not apply to instances of marginalized knowledge practices (e.g., postStratfordianism).
} 
The consequence for epistemological systems is, ironically, a form of epistemic injustice for its overzealous defenders. As Fricker (2007) points out, in cases of credibility excess, where a privileged knower is structurally granted epistemic authority, they can develop as a result "epistemic arrogance [such] that a range of epistemic virtues are put out of [their] reach, rendering [them] closed-minded, dogmatic, blithely impervious to criticism, etc.” (p. 20). As Pohlhaus (2017) puts it, "one cannot simply ignore other knowers and know well” (p. 16). One way to resist such a stance is to view open-mindedness as a second-order belief not about the belief itself but about your own fallibility as a believer: The thing one believes may be true, but as a knowing agent one is not infallible (Adler 2004).

As we shall see below, these epistemic virtues are also some of the very ones advocated in the Association of College and Research Libraries' Framework for Information Literacy for Higher Education (2015).

\section{Methods: The ACRL Framework for Information Literacy for Higher Education}

Officially adopted by the Association of College and Research Libraries (ACRL) in 2016, the Framework for Information Literacy for Higher Education frames information literacy (i.e., library instruction) as a social practice, rather than a set of discrete skills (ACRL Board of Directors, 2015). The Framework encourages a situated dialogue around the socio-cultural influences inherent in knowledge creation processes. As Nancy Foasberg (2015) notes, T] he Framework acknowledges that bias, privilege, and power are implicated in the production of information...to be information literate, a person not only must understand the process by which information is deemed "appropriate" but must also evaluate whether this process is a just one (pp. 708-9; italics added). 
For our purposes then, the Framework is an ideal tool for examining the ways in which "bias, privilege and power" play in marginalizing the SAQ, and to "evaluate whether this process is a just one." The Framework consists of six elements (ACRL Board of Directors 2015) ${ }^{6}$ :

\section{Authority Is Constructed and Contextual}

This first frame encourages students to understand the bases of existing authority in terms of what constitutes a credible source, but also to be aware of the structural biases that can lead to the creation of authorities and the reproduction of conventional wisdom. This frame is ontological.

\section{Information Has Value}

The second Frame considers the multiple "dimensions of value" possessed by sources of information, and stresses that "value may be wielded by powerful interests in ways that marginalize certain voices" (p. 16). This frame is axiological.

\section{Research as Inquiry}

This Frame encourages the researcher to be open to "asking increasingly complex or new questions" as there may be open and unresolved questions involving disagreement and debate requiring "diverse disciplinary perspectives" (p. 18). This frame is epistemological.

\section{Information Creation as a Process}

This frame encourages the researcher to understand how purpose and intended audience(s) can help determine the format the information product will take, be it an article, chapter, news item, video, podcast or book. This frame is materialist.

\footnotetext{
${ }^{6}$ The ACRL lists the Frames in alphabetical order, but they are arranged here to better represent a reasonably intuitive narrative of the research process, while acknowledging that such is never linear or consistent. Classification of the frames in terms of branches of philosophy and related concepts are original to the present author.
} 


\section{Searching as Strategic Exploration}

This Frame considers the strategic techniques involved research are both nonlinear and iterative, prompting successful researchers to look beyond a limited range of information sources and search terms. This frame is methodological.

\section{Scholarship as Conversation}

The student is made aware in this frame of how researchers and their outputs - peerreviewed articles, chapters, books, conferences etc. - contribute to a global conversation of shared and competing theories, perspectives and interpretations which evolve over time. This frame is dialogical.

\section{Analysis: Viewing Stratfordian Statements About the SAQ According to the ACRL Framework}

They clepe us drunkards and with swinish phrase soil our addition.

- Hamlet, Act I, sc. iv

\section{Authority Is Constructed and Contextual}

Many of the pioneering Shakespeare scholars of the Eighteenth through early Twentieth Centuries (such as Sidney Lee, E.K. Chambers and Edmund Malone) were amateur historians, in the sense that they were not university professors: The professionalization of academic Shakespeare scholarship is a purely mid- $20^{\text {th }}$ Century invention (Rubinstein, 2010). Yet orthodox defenders of the Stratford tradition routinely cite their own authority as academics in order to downplay and dismiss the credentials and accomplishments of post-Stratfordians - and indeed to criticize the very idea of questioning authorities.

This aversion to questioning authority is particularly evident in the writings of Paul Edmondson and Stanley Wells of the Shakespeare Birthplace Trust, who in the past decade 
produced the book Shakespeare Beyond Doubt (2013) and the brief tract Shakespeare Bites Back (2011), as well as the website 60 Minutes With Shakespeare (intended to rebut the Oxfordian motion picture Anonymous [Emmerich 2011]) which consisted of -- in revealingly patronizing words -- "break[ing] down the assault on Shakespeare into soluble spoonfuls for the general public" (Edmondson \& Leon, 2014, pp. 199). It must be stressed that the Trust is hardly a disinterested body, as it oversees a lucrative tourist and real estate enterprise that draws millions of people and generates millions of pounds to Stratford-Upon-Avon each year.

Edmondson and Wells are particularly relentless in asserting their authority as experts and in defending orthodoxy. For example, in Shakespeare Beyond Doubt Edmondson states, "There is...the loaded assumption that even though one may lack the necessary knowledge and expertise, it is always acceptable to challenge or contradict a knowledgeable and expert authority. It is not" (p. 225). He adds that the debate demonstrates a "clash between the professional Shakespeare scholar and the anti-Shakespearean amateur. The former employs often highly specialized knowledge; the latter denies it" (p. 227). In both cases, Edmondson offers a loaded assumption of his own: that post-Stratfordians lack the necessary knowledge and expertise, and that that of the professional is "highly specialized." In Shakespeare Bites Back Edmondson and Wells (2011) further assert, "[t]urning to historical facts without knowledge and understanding is dangerous and foolish. Anti-Shakespearian rhetoric seeks to convince those who fail to perceive the false premises on which it is based" (Edmondson \& Wells, 2011, p. 12). Again, they declare that postStratfordians lack knowledge, dismissing the thousands of books and articles contributed by 
skeptics over more than a century and a half ${ }^{7}$. This also attributes bad faith (epistemic vice) to post-Stratfordians in that they are assumed to be deliberately misleading the gullible.

This example highlights one of the most significant denials one encounters in the literature: that all Shakespeare scholars reject post-Stratfordian arguments, and the concomitant proposition that anyone who is a doubter is not a scholar. For example, Rosenblum (2017) states, On one point scholars agree: the William Shakespeare who wrote the plays and poems ... was born in Stratford-upon-Avon in 1564, and died there fifty-two years later. Since the nineteenth century, various nonscholars have proposed dozens of alternative authors .... (p. xiv)

Bruce Danner (2011) dismisses skeptics as a "group of amateur readers" who are "little more than sincere enthusiasts of Shakespeare" searching for "alternative Shakespeares with their own unaided and often underinformed efforts" (p. 157). In Shakespeare Bites Back, Edmondson and Wells (2011) also observe,

We see...a disconnection between the professional historians and Shakespeare scholars on one side and well-educated non-specialists on the other. Our approach to the facts and historical evidence is complex and is informed by a deep knowledge in order to understand them (p. 34).

These assertions ignore the fact that many post-Stratfordians are themselves degreed scholars. As of this writing (early 2020) the Shakespeare Authorship Coalition's Declaration of Reasonable Doubt petition includes 736 academic signatories (Shakespeare Authorship Coalition). Yet Stratfordians often fall back on the idea that their "approach to the facts" is

\footnotetext{
${ }^{7}$ While it is agreed that modern doubts about Shakespeare began with the 1848 book The Romance of Yachting (Hart, 1848) there is substantial evidence that Shakespeare's contemporaries were aware that there was a secret author behind the name. See Wildenthal 2019.
} 
"complex" and uniquely informed in order to elevate their status as knowers while dismissing post-Stratfordian claims without actually addressing them. Such elitism is rather rich, given the orthodox habit of accusing skeptics of "snobbery" (Wildenthal 2019).

As well - and contrary to the origins of Shakespeare scholarship - this conflation of credentials and institutional affiliation with authority erases the significant contribution of such independent scholars as Diana Price, whose Shakespeare's Unorthodox Biography (2001) demonstrated the unique (and deadly) absence of any literary paper trail for William Shakspere that might have documented a writing career; Bonner Miller Cutting, whose numerous articles (collected in Necessary Mischief [2019]) look past conventional assumptions about the political and historical contexts of the Elizabethan era to reveal how startlingly unlikely Shakspere's authorship would be; and Katherine Chiljan, whose book Shakespeare Suppressed (2011) lists over 90 "too early" contemporary references in Elizabethan literature to the works of Shakespeare, convincingly arguing that Shakspere would have been too young to have been the author.

Yet these exclusions are not confined to claims of rarified expertise: Stratfordians - or the Shakespeare Birthplace Trust at any rate - position themselves as moral authorities as well. In responding to the "bully[ing]... antagonism generated by anti-Shakespearians" (Edmondson, 2013, p. 227), the Trust makes the "deeply moral point" of condemning their "denial of evidence" (Edmondson and Wells, 2011, p. 19), claiming that its own online campaign against the film Anonymous constituted nothing less than "championing freedom and democracy" (Edmondson and Leon, 2014, p. 193).

Summary: Where the ACRL Framework advises skepticism towards authority and recognizes that many different knowledge producers may be authoritative, Edmondson, Wells and 
other leading Stratfordians condemn the questioning of authority, while redefining the category "scholar" to exclude all post-Stratfordians, whether they are university professors or independent researchers. That self-ascribed epistemic and moral authority triumphantly conjoined to suppress dissent should be vaunted as defending freedom and democracy - rather than being understood as being contrary to both - reveals a troubling illiberal undercurrent to this rhetoric. We are also instructed by the Framework to recognize authorities with conflicts of interest: In the case of Edmondson and Wells, it should be understood that their association with a lucrative Shakespeare-related tourist destination through the Shakespeare Birthplace Trust renders them as not disinterested observers.

\section{Information Has Value}

Following the release of the film Anonymous (Emmerich, 2011), the Shakespeare Birthplace Trust solicited essays that would be published in the 2013 book Shakespeare Beyond Doubt: Evidence, Argument, Controversy edited by Paul Edmondson and Stanley Wells (Edmondson and Wells, 2013). Edmondson is the Head of Research and Knowledge and Director of the Stratford-upon-Avon Poetry Festival for The Shakespeare Birthplace Trust, while Wells is the Trust's Honorary President. Published by Cambridge University Press, the book was widely reviewed in respected journals (including in the Times Literary Supplement and SEL: Studies in English Literature 1500-1900), and is, as of this writing, held in 316 libraries around the world. In response, the Shakespeare Authorship Coalition produced their own collection of postStratfordian essays entitled Shakespeare Beyond Doubt? Exposing an Industry in Denial, edited by John M. Shahan and Alexander Waugh (Shahan and Waugh, 2013). Shahan is the Chairman of the Shakespeare Authorship Coalition, while Waugh a writer and critic and the Coalition's Honorary President. Published by Llumina Press, a self-publishing print-on-demand company, 
their book was reviewed primarily in post-Stratfordian venues (e.g., Rubin, n.d.) and is held in only 33 libraries around the world.

That two almost identically-titled books released in the same year met such different responses provides an excellent illustration of how structures of value serve to marginalize the SAQ: A major academic publisher releases an orthodox defense of the status quo sponsored by a not-disinterested British charity and achieves success through the conventional tools of the book trade including sales to libraries, while the dissident collection is self-published and barely noticed. ${ }^{8}$

However, it must be stressed that this marginalization is not hidden or disguised - rather it is openly celebrated by orthodox scholars and journalists. As Canadian novelist and essayist Stephen Marche observed of the post-Stratfordians in the pages of the New York Times, "The problem is that not everybody does deserve a say. Just because an opinion exists does not mean that the opinion is worthy of respect. Some people deserve to be marginalized and excluded" (2011, para. 14).

Summary: The ACRL Framework acknowledges that how information is valued in society can serve powerful interests while marginalizing other voices; as a consequence researchers should examine their own information privilege. In this case, current structures of value reinforce and reproduce the dominant narrative, to the approval of the orthodox.

\section{Research as Inquiry}

As we learned in the introduction to this chapter, some Stratfordian scholars admit that the extant documentation is scant, and that the entire enterprise of Shakespearean biography is highly problematic and replete with speculation (Danner, 2011; Ellis, 2014). However, for Danner, the

\footnotetext{
${ }^{8}$ For a further discussion about the SAQ, libraries and the publishing industry, see Dudley 2015.
} 
problem appears to be rooted in the scholars' inability so far to construct a compelling biography, not in the actual impossibility of doing so on the basis of the available evidence; so for him the writings of post-Stratfordians are but "irrational fictions" (p. 145). For his part, Robert Sawyer, in his book Marlowe \& Shakespeare: The Critical Rivalry (2017) compares the imaginative fictions of some Shakespeare biographers to the theories of 9/11 "Truthers;" yet scarcely a page later and without a hint of self-awareness - calls anti-Stratfordians "our own version of the 9/11 'Truthers"” (p. 325). It does not seem to occur to Ellis, Danner or Sawyer that, if an absence of evidence is so complete it requires biographers to resort to fiction, then that probably indicates a need to be asking different questions, and to consider the life of that individual a matter of open inquiry. Yet, acknowledging the highly problematic nature of the evidence while still adhering to the dominant narrative is apparently the source of considerable cognitive dissonance.

Of course, Sawyer's remarks revisit the standard trope of comparing post-Stratfordians to conspiracy theorists, the assumption being that because all conspiracy theories are equally baseless, this makes them by definition unreasonable and eminently dismissible. Scott McCrea, in his The Case for Shakespeare: The End of the Authorship Question (2005) makes this explicit in his final chapter entitled, "All Conspiracy Theories are the Same” (p. 215-223).

Edmondson and Wells begin their Shakespeare Beyond Doubt (2013) by referring to skeptics as anti-Shakespearians, a proposition that pejoratively labels the post-Stratfordian as “attacking” Shakespeare. More bewildering, however, is their argument that the term antiStratfordian should be rejected because it "allows the work attributed to Shakespeare to be separated from the social and cultural context of its author" (p. 32). This is, of course sheer 
sophistry to say nothing of circular reasoning: The debate over the identity of the author can't presume the location in which the works were written. ${ }^{9}$

More disingenuous reasoning arises in Edmondson's and Wells' Shakespeare Bites Back (2011). In referring to the more than 70 candidates that have been proposed over the centuries, they sweepingly assert that "all of these nominations are equally invalid; none has a greater claim than any of the others... all the suggestions rest on equally false premises (pp. 10-12)." This elides the reality that only a few of these candidates have any significant support at this point, or are the subjects of entire libraries' worth of books as are Oxford, Bacon and Marlowe. The more significant problem here however, is that this is a highly fallacious and unsupportable statement: One cannot claim that all potential counterarguments are equally invalid without actually considering the evidence for each.

More fallacious attempts to dismiss the possibility of alternative candidates are espoused by other scholars. Joseph Rosenblum, in his chapter on the SAQ in his reference work The Definitive Shakespeare Companion declares that "no evidence [for other candidates] can exist." As I noted in my review of this chapter,

It's one thing to argue that the available evidence fails to meet the burden of proof, or is insufficiently compelling. It's even acceptable to argue that no such evidence may ever be found. But it's quite another to declare, with the omniscience usually reserved for deities, the absolute non-existence of something which, all things being equal, could quite reasonably and conceivably exist (Dudley, 2018, p. 18).

Furthermore, Edmondson and Wells (2011) appeal to false analogies when they "scorn any anti-Shakespearian argument which begins with the formulation, 'Shakespeare couldn't have

\footnotetext{
${ }^{9}$ In any case, claims for the presence of Warwickshire dialect in the canon do not withstand scrutiny (Barber 2018).
} 
written the works because...' This is the equivalent to saying 'how could the world possibly be round because our eyes tell us that it is flat?"' (p. 35). These propositions are, both in form and content, completely incomparable and once again serve to equate a debate over historical evidence to patent irrationality.

From the perspective of virtue epistemology, Stratfordians appear to be positively terrified of the Authorship Question, which they characterize as "ultimately a dangerous phenomenon which can lead to conspiratorial narratives fueled by denials of historical evidence" (Edmondson \& Wells (2013, p. 235), as well as being "an entirely parasitic phenomenon, attacking the truth in order to feed off its life-blood...attach[ing] itself, leech-like, to a healthy body" (2011, p. 25). Indeed, in the view of Stanley Wells, "it is dangerous and immoral to question history" (as quoted in Waugh 2018). In the face of such a terrible threat, those who profess to have an "open mind" must hold ulterior motives (Edmondson, 2013, p. 226).

Summary: Where the ACRL Framework encourages the researcher to regard gaps in information within fields of inquiry as an opportunity to ask deeper and more complex questions, and to consider these as unresolved matters requiring an open mind, most Stratfordian scholars display dogmatic resolve to ignore or explain away such gaps. The mere act of asking questions is pathologized, as is the disposition towards keeping an open mind.

\section{Information Creation as a Process}

It is a common criticism levelled against post-Stratfordians that they don't subject their theories to peer review in academic journals as do ordinary scholars. The reality is that those few who do manage to get their work published in mainstream Shakespeare journals only do so because they self-censor their positions on the SAQ from their work (Waugaman, 2014). Having long been systematically shut out of conventional peer-reviewed journals and conferences, post- 
Stratfordians are increasingly turning to the Web to publish their research and commentary in a wide range of formats, including newsletters, blogs, videos and podcasts (Shapiro, 2010, p. 8). Here one can find a rich vitality of production, including the Shakespeare Authorship Coalition's online campaign the Declaration of Reasonable Doubt, the journals and newsletters of the Shakespeare Oxford Fellowship including Brief Chronicles and The Oxfordian, Keir Cutler's entertaining YouTube videos, the Shakespeare Oxford Fellowship's Don't Quill the Messenger podcasts and Hank Whittemore's methodical list of "100 Reasons Why Oxford Was Shakespeare" (Whittemore, 2011).

It is generally underappreciated that the Web and digital archives and repositories in particular have greatly accelerated the progress on research on the authorship of Shakespeare by making globally available historical documents that were once physically confined to libraries and archives, and therefore only accessible to a few dedicated researchers (Waugh, 2014). Still, the response from orthodox scholars has been to dismiss such contributions, and indeed the formats themselves. Matt Kubus, in his chapter in Shakespeare Beyond Doubt (2013) derides the "democratization" of the authorship discussion online, stating that "the blogs of the amateur are an ideal platform for those unusually extreme cases for Shakespeare authorship" (p. 59). One would have thought that the 2014 anthology Shakespeare and the Digital World: Redefining Scholarship and Practice edited by Christie Carson and Peter Kirwan would have been an appropriate place to have acknowledged the legitimacy of these venues and the work of postStratfordians, as it dealt with digital formats such as open-access journals, blogs, online courses and e-texts relating to Shakespeare studies. However, Kirwan (2014) only mentions postStratfordian websites in passing and derisively as "conspiracy hubs" (p. 61). In what must have 
been a deliberate decision on the part of the editors, no reference is made to online postStratfordian knowledge production (Carson \& Kirwan, 2014).

Summary: Where the ACRL Framework recognizes that purpose and intended audience can result in a wide range of formats - some of them new and emergent - but that researchers should not equate the product with any underlying creation processes, we see in the mainstream rejection of digital information produced by post-Stratfordians both the blanket dismissal of these formats and invidious assumptions about underlying processes, i.e., conspiracy theories.

\section{Searching as Strategic Exploration}

The nature and scale of publications related to post-Stratfordian theories - especially concerning the candidacy of Edward de Vere, $17^{\text {th }}$ Earl of Oxford - have been particularly robust for the past 20 years. Examples include such notable books as Shakespeare's Unorthodox Biography (Price, 2001), Shakespeare by Another Name (Anderson, 2005) and Shakespeare Suppressed (Chiljan, 2011).

However, recent Stratfordian books seeking to debunk post-Stratfordian theories have conspicuously avoided referring to any of these publications, instead revisiting well-worn paths of ridicule directed at $19^{\text {th }}$ Century skeptics, notably Delia Bacon. The bibliography in Shakespeare Beyond Doubt (2013) confirms that Edmondson and Wells managed to ignore a half-century worth of relevant literature, while Joseph Rosenblum's chapter on the SAQ in his Definitive Shakespeare Companion (2017) relies heavily on orthodox and dated work: in addition to Shapiro (2010), and Edmondson and Wells (2013), he cites books published in the 1950s and 60s, with only one - The Shakespeare Controversy, by Warren Hope and Kim Holston (1992) - being from an Oxfordian viewpoint, and several decades old at that. An undergraduate paper with such a dated and one-sided bibliography would likely receive a failing grade. Such omissions can hardly 
be accidental and attest to the inability of leading Stratfordians to respond in good faith to the weakness of their own position.

Summary: Where the ACRL Framework states that experienced scholars look beyond a limited range of sources, we see in the work of orthodox defenders of the Stratford myth a studied reliance on older publications and what must be a deliberate strategic decision to ignore recent relevant scholarship.

\section{Scholarship as Conversation}

In his 2010 book Contested Will, James Shapiro offers a rare mainstream admission that the academy has "walled off" the SAQ from mainstream scholarship, and enforces this "taboo" by shutting out post-Stratfordians from scholarly journals (Shapiro, 2010, pp. 3, 8). In 2014, a scholarly controversy that made international news illustrates this gatekeeping in action: The Italian journal Memoria di Shakespeare was preparing for a special issue on the biography of Shakespeare to be published the following year, when one of the accepted articles was subsequently rejected. The article in question, "The Psychology of Shakespearean Biography” by Oxfordian Richard Waugaman, explored the phenomenon of the taboo against the SAQ and the unflattering socio-psychological reasons why Stratfordians so rigorously enforce it (see Waugaman, 2014). It had originally been received by the editors as "absolutely pertinent" to the issue; however, following the departure of the editors, one of the new editors Gary Taylorprofessor at Florida State University and co-editor on the then-in-progress New Oxford Shakespeare ${ }^{10}$ - decided to reject the article, calling it "profoundly unscholarly" and compared it to Holocaust denial. When Waugaman took offence, Taylor responded,

\footnotetext{
${ }^{10}$ In this edition of the plays, Taylor and his co-editors caused considerable controversy of their own with their dubious claims that up to $40 \%$ of the text of the canon was written by other contemporaries of Shakespeare. See Dudley, Goldstein and Maycock, 2017.
} 
I compared it to the work of Holocaust-deniers not because the damage to Shakespeare is comparable to the damage to the millions of people killed by the Nazis, but because Waugaman's work depends upon the same kind of conspiratorial claims. You cannot reason with such claims, because they dismiss empirical evidence as just another conspiracy. The idea that anti-Stratfordian zealots are 'censored' is ridiculous (Reisz, 2014, pp. 10-11).

Elsewhere however, such censorship of post-Stratfordians is openly acknowledged and celebrated. At Wikipedia, tightly-controlled gatekeeping of Shakespeare-related content by the editors - primarily the self-appointed Tom Reedy - results in the swift deletion of any postStratfordian edits. As a result, Wikipedia's Shakespeare pages "tend[] towards orthodoxy, favoring traditional, authorized positions” (Moberly, 2018, 91). As Mark Anderson recounts, initially Wikipedia’s “Shakespeare Authorship Question” article was reasonably balanced, with two editors - one Stratfordian, the other an Oxfordian - working together cooperatively. This collegial atmosphere ended in 2009 when Reedy and another anonymous Stratfordian took over the page to give it a decidedly Stratfordian perspective, initiating a dispute that saw the Oxfordian editor banned from the article (Anderson, 2011). In the closing pages of Shakespeare Beyond Doubt Edmondson and Wells commend Reedy as an "unsung hero" for spending "countless hours ensuring that the site remains fact rather than faith based" (Edmondson \& Wells 2013, 240).

Summary: Where the ACRL Framework encourages researchers to regard fields of inquiry as open and contested, requiring ongoing negotiation and conversation between scholars, Stratfordians brook no conversation that does not adhere to the parameters of the orthodox biography, actively shutting out any non-conforming speakers from the conversation. 


\section{Discussion}

According to most mainstream scholarship and media analysis, the Shakespeare Authorship Question is a dangerous fringe belief held by zealots, snobs and conspiracy theorists, a growing symptom of our "post-truth" age and comparable to flat-Earth beliefs and Holocaust denial. As such, it may be dismissed and ignored, or only cited to be rebutted. Any gaps in the evidence for - and our understandings of - Shakespeare may be explained away by documents being lost to history (e.g., Shakespeare's "lost years") or else the "miracle" of genius and imagination.

However, when viewed through the theoretical lens of epistemic virtue and measured against an external standard of robust research practices and dispositions in the form of the ACRL Framework for Information Literacy for Higher Education, this rhetoric is revealed to constitute a pattern of epistemic vice and oppression, and as such is quite incompatible with sound scholarship and pedagogy.

The Frame Authority Is Constructed and Contextual demonstrates that Stratfordians espouse - indeed, demand - an uncritical acceptance of authority, namely their own. The very act of questioning their authority is viewed with suspicion and contempt. Post-Stratfordians are consistently rejected as reliable speakers and suffer testimonial injustice (Fricker, 2007) as a result, in favour of these traditional authorities - many of whom have strong vested interests in the maintenance of the status quo.

Information Has Value reveals the extent to which current structures and practices in scholarly publishing lend unwarranted value to Stratfordian voices while shutting out postStratfordians, and this marginalization is met with unreflexive approval. As a result, the academy 
and the mass media reinforce and faithfully reproduce the dominant narrative, thereby maintaining the epistemological system (Dotson 2014) of orthodox Shakespeare studies.

Furthermore, Searching as Strategic Exploration demonstrates the willfully anemic sourcing of leading Stratfordian publications, as the result of apparent decisions not to cite recent post-Stratfordian scholarship. These lapses are consistent with Kidd's notions of poor epistemic conduct, e.g., deliberately ignoring evidence (Kidd, 2016); and Information Creation as a Process shows how these mechanisms of exclusion extend across all formats. In the words of Husting and Orr (2007), these practices "perform boundary maintenance" in Shakespeare studies such that “certain ways of knowing, thinking, and talking about power are encouraged while others are rendered abnormal" (p. 144) - processes referred to by Sullivan (2000) as "forum control."

Most significantly, Research as Inquiry exposes Stratfordian scholarship as a closed, circular system of inquiry dominated by logical fallacies, resolutely shutting itself off from potentially fruitful pathways of investigation. The ubiquitous accusation of "conspiracy theory" is clearly a "mechanism of exclusion" designed to "pre-empt[] the scholarly and investigation process" (Husting \& Orr, 2007, pp. 131; 146).

Finally, Scholarship as Conversation depicts an academic community deviating from standard collegial practice by actively excluding post-Stratfordians from the scholarly conversation. Instead of a praxis of epistemic humility, Stratfordian scholars and opinion-makers adopt a stance of unapologetic triumphalism. The oppressions faced by post-Stratfordians as a consequence are very real: their academic freedom infringed upon, their work is excluded from mainstream books and journals in Shakespeare studies, and their career choices and opportunities are circumscribed accordingly. The effects become intergenerational: as Oxfordian Wally Hurst notes, their movement is "too old, too white and too male" (Hurst, 2018). Without institutional 
and cultural infrastructure - especially an education system that reproduces post-Stratfordian knowledge - it is primarily those who are already epistemologically privileged in other aspects of their lives that have the resources to be engaged in the issue, and then only with other like-minded scholars in purpose-built venues.

In short, these rhetorics of exclusion demonstrate a pronounced degree of bad faith on the part of many orthodox scholars and media opinion-makers, representing a consistent pattern of epistemic vice resulting in epistemic injustice and oppression against post-Stratfordian doubters.

Yet, the costs of these vice-charges are not borne wholly by their intended targets: As Fricker (2007) argues, the mainstream perpetrators of epistemic injustice themselves become its victims by growing arrogant and "closed-minded, dogmatic, blithely impervious to criticism, etc." and in so doing deprive themselves of knowledge they might have otherwise pursued (p. 20). Ultimately then, this rhetoric does not just foreclose the academic freedom of post-Stratfordians, it limits the thinkable and sayable for everyone who cares about Shakespeare, including Stratfordians themselves. To paraphrase Macbeth, this even-handed injustice commends the ingredients of their poison'd chalice to their own lips.

\section{Conclusion: Towards Epistemic Humility and Creative Inquiry in the SAQ}

Orthodox Shakespeare scholarship is the history of shackled thought, of brainwashed intellect, of curtailed curiosity. It makes one long for the day, perhaps not far off, when the full intellectual potential of Shakespeare scholars will be unleashed, liberated from conscious and unconscious constraints imposed by the authorship orthodoxy.

- Richard Waugaman ${ }^{11}$

\footnotetext{
${ }^{11}$ Waugaman 2008, 8.
} 
The suppression of research and pedagogy concerning the authorship of the works of Shakespeare represents a significant but under-examined example of a threat to academic freedom originating from within the academy, but also one with significant support from many major media outlets. In exploring this systemic infringement of academic freedom, this chapter has portrayed a scholarly mainstream whose campaign to delegitimize and foreclose legitimate lines of inquiry has necessitated confining itself to an epistemological prison, because it refuses to broaden either its scope of inquiry or its community of scholars. It demonstrates the extent to which any field of inquiry has the potential to become so comfortable and complacent with its paradigmatic assumptions that it risks arrogance, ossification and the loss of innovation.

To transcend or avoid patterns of epistemic injustice and ensure the internal maintenance academic freedom, scholars should aspire to what Alfonso Montuori refers to as creative inquiry: a rejection of the industrial-age ethos of "reproductive education" in which students are merely expected to consume and repeat knowledge provided by experts who are certain about their own certainties, to instead embrace uncertainty, complexity and the realization of all we do not know. Montuori argues that such an "ignorance-based worldview" requires "an attitude of epistemological humility, a starting point of not-knowing and wonder" (p. 67).

Instead of condemning the "zealotry" of "anti-Shakespeareans" and barring them from participating in the scholarly conversation, the Shakespeare academy needs to welcome postStratfordians as fellow Shakespeareans, joined together in their shared passion for the plays and poems and a desire to pass their love to the next generation. The Shakespeare professoriate needs to grant academic freedom equally to post-Stratfordians and to themselves, instead of fatally circumscribing their own investigations and those of their colleagues and students. Only then can 
the study of this magnificent, brilliant and timeless author become a creative inquiry, filled with wonder and possibility.

The grace of Shakespeare is that there is always another side to things; there is always doubt.

-- Jennifer Michael Hecht ${ }^{12}$

\section{Acknowledgements}

The author would like to thank the following people for their assistance in the preparation of this chapter: Bryan Wildenthal for sharing a pre-publication copy of his book Early Shakespeare Authorship Doubts; and John Dobson, Wally Hurst, Rhiannon Jones, Deborah Power-DeMille, Eva Revitt, Roger Stritmatter, Stewart Wilcox and John Wright for reading and providing valuable comments and corrections to earlier drafts. Thanks as well to the members of the Facebook group "ShakesVere - Edward de Vere, Earl of Oxford, 'Shakespeare' by Another Name" for their suggestions. Finally, I would like to acknowledge the tireless InterLibrary Loan staff at the University of Winnipeg Library for providing me with timely access to many of the sources used in this chapter.

\footnotetext{
${ }^{12}$ Hecht 2004, 306.
} 
References

ACRL Board of Directors. (2015). Framework for information literacy for higher education. Association of College and Research Libraries.

Adler, J. (2004). Reconciling open-mindedness and belief. Theory and Research in Education, 2(2), 127-142.

American Association of University Professors. (2003, December 3). Academic bill of rights. https://www.aaup.org/report/academic-bill-rights

Anderson, M. (2006). "Shakespeare" by another name: The life of Edward de Vere, earl of Oxford, the man who was Shakespeare. Gotham Books.

Anderson, M. (2011, July 28). Wikipedia's Shakespeare problem. IEEE Spectrum. https://spectrum.ieee.org/at-work/education/wikipedias-shakespeare-problem

Barber, R. (2018). Shakespeare and Warwickshire dialect claims. Notes and Queries, 65(4), 549551. https://doi:10.1093/notesj/gjy133

Bate, J. (1998). The genius of Shakespeare. Oxford University Press.

Carson, C., \& Kirwan, P. (2014). Shakespeare and the digital world: Redefining scholarship and practice. Cambridge University Press.

Chiljan, K. (2011). Shakespeare suppressed: The uncensored truth about Shakespeare and his works: A book of evidence and explanation. Faire Editions. 
Crinkley, R. (1985). New perspectives on the authorship question. Shakespeare Quarterly, 36(4), 515-522.

Cutting, B. (2018). Necessary mischief: Exploring the Shakespeare authorship question. Minos Publishing Company.

Danner, B. (2011). The anonymous Shakespeare: Heresy, authorship, and the anxiety of orthodoxy. In Starner, J., \& Traister, B. (Eds.), Anonymity in early modern England: 'What's in a name?' (pp. 143-158). Ashgate.

Dotson, K. (2014). Conceptualizing epistemic oppression. Social Epistemology, 28(2), 115-138. https://doi:10.1080/02691728.2013.782585

Dudley, M. (2015). Knowledge Ill-Inhabited: The Subjugation of post-Stratfordian scholarship in academic libraries. The Oxfordian 17, 27-61.

Dudley, M. (2018). [Review of the chapter "The authorship questions" by J. Rosenblum in The Definitive Shakespeare companion: Overviews, documents, and analysis, edited by J. Rosenblum. Shakespeare Oxford Newsletter, 54(4), 17-21.

Dudley, M., Goldstein, G., \& Maycock, S. (2017). All that is Shakespeare melts into air [Review of the book The New Oxford Shakespeare Authorship Companion, edited by G. Taylor \& G. Egan]. The Oxfordian, 19, 195-208.

Edmondson, P., \& Leon, A. J. (2014). Changing a culture with the Shakespeare birthplace trust: Championing freedom and democracy. In C. Carson \& P. Kirwan, (Eds.), Shakespeare and 
the Digital World: Redefining Scholarship and Practice (pp. 193-201). Cambridge University Press.

Edmondson, P. \& Wells, S. (2011). Shakespeare bites back: Not so anonymous. The Shakespeare Birthplace Trust. http://bloggingshakespeare.com/shakespeare-bites-back-free-book

Edmondson, P., \& Wells, S. (2013). Shakespeare beyond doubt: Evidence, argument, controversy. Cambridge University Press.

Ellis, D. (2012). The Truth about William Shakespeare: Fact, fiction and modern biographies. Edinburgh University Press.

Emmerich, R. (Director). (2011). Anonymous [film]. Sony Pictures Home Entertainment.

Foasberg, N. M. (2015). From standards to frameworks for IL: How the ACRL framework addresses critiques of the standards. Portal: Libraries and the Academy, 15(4), 699-717.

Fricker, M. (2007). Epistemic injustice: Power and the ethics of knowing. Oxford University Press.

Gilvary, K. (2018). The fictional lives of Shakespeare. Routledge.

Green, D. (2019, May 13th). Was Shakespeare a woman? The Spectator. https://spectator.us/shak espeare-woman-atlantic/

Hampton-Reeves, S. (2013). The 'Declaration of reasonable doubt.' In P. Edmondson \& S. Wells (Eds.), Shakespeare beyond doubt: Evidence, argument, controversy (pp. 201-214). Cambridge University Press. 
Hart, J. (1848). The romance of yachting: Voyage the first. Harper \& Bros.

Hecht, J. M. (2004). Doubt: A history: The great doubters and their legacy of innovation, from Socrates and Jesus to Thomas Jefferson and Emily Dickinson. HarperOne.

\section{Hope, W., \& Holston, K. (2009). The Shakespeare controversy: An analysis of the authorship theories (2nd edition). McFarland.}

Hurst, W. (2018, February 13). Academic freedom, English professors, and the Shakespeare authorship question [Video]. YouTube. https://youtu.be/4KL9rmkZBIY

Husting, G., \& Orr, M. (2007). Dangerous machinery: "Conspiracy theorist" as a transpersonal strategy of exclusion. Symbolic Interaction, 30(2), 127-150.

Jackson, R. (2012). Unknown knowns: The subjugated knowledge of terrorism studies. Critical Studies on Terrorism, 5(1), 11-29. https://doi:10.1080/17539153.2012.659907

Kempner, J., Merz, J. F., \& Bosk, C. L. (2011). Forbidden knowledge: Public controversy and the production of nonknowledge. Sociological Forum, 26(3) 475-500.

Kidd, I. J. (2016). Charging others with epistemic vice. The Monist, 99(2), 181-197. https://doi:10. 1093/monist/onv035

Kirwan, P. (2014). Introduction: Pedagogy. In C. Carson \& P. Kirwan, (Eds.), Shakespeare and the digital world: Redefining scholarship and practice, (pp. 58-62). Cambridge University Press. 
Kubus, M. (2013). The unusual suspects. In P. Edmondson \& S. Wells, (Eds.), Shakespeare beyond doubt: Evidence, argument, controversy, (pp. 49-60). Cambridge University Press.

Lewis, C. (1970). God in the dock: Essays on theology and ethics (W. Hooper, Ed.). William B. Eerdmans Publishing Company.

Marche, S. (2011, October 21st). Wouldn't it be cool if Shakespeare wasn't Shakespeare? New York Times https://tinyurl.com/y483wzea

McCrea, S. (2005). The case for Shakespeare: The end of the authorship question. Praeger.

Moberly, D.C. (2018). “Once more to the breach!” Shakespeare, Wikipedia's gender gap and the online, digital elite. In S. Neill (Ed.), Broadcast your Shakespeare: Continuity and change across media, (pp. 87-104). Bloomsbury Arden Shakespeare.

Montuori, A. (2012). Creative Inquiry: Confronting the challenges of scholarship in the 21st century. Futures, 44(1), 64-70.

Ogburn, C. (1992). The mysterious William Shakespeare: The myth \& the reality (2nd edition). EPM Publications.

Pohlhaus, G. (2017). Varieties of epistemic injustice 1. In I. Kidd, J. Medina and G. M. Pohlhaus, (Eds.), The Routledge handbook of epistemic injustice, (pp. 13-26). Routledge, Taylor \& Francis Group.

Price, D. (2001). Shakespeare's unorthodox biography: New evidence of an authorship problem. Greenwood Press. 
Pritchard, D. (2014). Re-evaluating the epistemic situationist challenge to virtue epistemology. In A. Fairweather \& O. Flanagan (Eds.), Naturalizing epistemic virtue, (pp. 143-154). Cambridge University Press.

Reisz, M. (2014, September 11th,). Much taboo, but not about nothing. Times Higher Education, $10-11$.

Rosenblum, J. (2017). The authorship questions. In J. Rosenblum (Ed.), The Definitive Shakespeare companion: Overviews, documents, and analysis (vol. 1), (pp. 79-94). Greenwood.

Rubin, D. (n.d.). Doubt vs. doubt. The Shakespeare Oxford Fellowship. https://tinyurl.com/y3arr9 $\underline{\text { wd }}$

Rubinstein, W. D. (2010). The Authorship question: An historian's perspective. Continuum International Publishing.

Rylance, M. (2019, June 8th). Keep questioning Shakespeare's identity. The Atlantic. https://tinyu rl.com/y66k67pjf

Sagan, C. (1979). Broca's brain: Reflections on the romance of science. Random House.

Sawyer, R. (2017). Marlowe and Shakespeare: The critical rivalry. Palgrave Macmillan.

Schoenbaum, S. (1991). Shakespeare's lives. Clarendon Press.

Shahan, J. M., \& Waugh, A. (2013). Shakespeare beyond doubt?: Exposing an industry in denial. Shakespeare Authorship Coalition. 
Shakespeare Authorship Coalition. (n.d.). Declaration of reasonable doubt about the identity of William Shakespeare. Retrieved February 24th, 2020 from https://doubtaboutwill.org/declara $\underline{\text { tion, }}$

Shapiro, J. (2010). Contested will: Who wrote Shakespeare? Simon \& Schuster.

Shapiro, J. (2019a, June 8th). Shakespeare wrote insightfully about women. That doesn't mean he was one. The Atlantic. https://tinyurl.com/vjky6e3

Shapiro, J (2019b, August $\left.6^{\text {th }}\right)$. An unexpected letter from John Paul Stevens, Shakespeare skeptic. The New Yorker. https://tinyurl.com/y4tta9sc

Sullivan, D. (2000). Keeping the rhetoric orthodox: Forum control in science. Technical Communication Quarterly 9(2), 125-146.

Turk, J. (Ed.) (2008). Universities at risk: How politics, special interests and corporatization threaten academic integrity. James Lorimer \& Company, Ltd.

Turk, J. (Ed.). (2014). Academic freedom in conflict: The struggle over free speech rights in the university. James Lorimer \& Company.

Washburn, J. (2006). University inc.: The corporate corruption of higher education. Basic Books.

Waugaman, R. (2008). Review of A.D. Nuttall, "Shakespeare the thinker." Shakespeare Matters 7(4), 8-11.

Waugaman, R. (2014). The psychopathology of Stratfordianism. Moniment, 10, 222. 
Waugh, A. (2014). Shakespeare in court. [Kindle single]. Retrieved from Amazon.ca

Waugh, A. (2018). Shakespeare birthplace trust exposed. [Video]. YouTube. https://youtu.be/ERJ $\underline{\text { S-NWZ7Ns }}$

Whittemore, H. (2011). 100 reasons why Oxford was Shakespeare. Retrieved March $17^{\text {th }}, 2020$ from https://tinyurl.com/ry6jbq4

Wildenthal, B.H. (2016). Remembering Rollett and debunking Shapiro (Again). Thomas Jefferson School of Law Research Paper No. 2899575 (2016, rev. 2017).

Wildenthal, B.H. (2019). Early Shakespeare authorship doubts. Zindabad Press.

Williams J. (2016) Teaching students to censor: How academics betrayed free speech. In: Slater T. (Ed.), Unsafe space: The crisis of free speech on campus, (pp. 47-57). Palgrave Macmillan.

Wilson, J. K. (2008). Patriotic correctness: Academic freedom and its enemies. Paradigm Publishers.

Winkler, E. (2019a). Was Shakespeare a woman? The Atlantic (June $\left.7^{\text {th }}\right)$. https://www.theatlantic. com/magazine/archive/2019/06/who-is-shakespeare-emilia-bassano/588076/

Winkler, E. (2019b). Elizabeth Winkler replies: The Atlantic (June $8^{\text {th }}$ ). https://www.theatlantic. com/letters/archive/2019/06/readers-discuss-debate-over-shakespeares-identity/591166/ 